\title{
BIOGRAPHICAL SKETCH OF BRIGADIER GENERAL BENJAMIN STONE ROBERTS.
}

\author{
BY THE EDITOR.
}

This officer was born in Manchester, Vt., on the 18th of Nov., 1810. His father, General Martin Roberts, was a native of the same town. He is descended directly from Revolutionary sires, his grandfathers on the father and mother's side having been soldiers in the war of the Revolution. General Christopher Roberts, his grandfather on his father's side, was with Gen. Ethan Allen at the capture of Ticonderoga, and was the soldier who seized the sentinel and carried him from his post, opening the entrance to the commanding General's quarters, where the memorable demand for the surrender of the Fort, "in the name of God Almighty and the Continental Congress," was made by Ethan Allen. His grandfather, on his mother's side, was Captain Luther Stone, a Commissary in the Revolution.

General Roberts was educated at West Point, graduated in 1835, and was commissioned a Second Lieutenant in the First Regiment of Dragoons. He resigned in 1839, and was appointed by the Governor of New York principal Engineer on the Ogdensburg and Champlain Railroad. In 1840, he was appointed Assistant Geologist of the State of New York, and assigned especially to the mineralogical survey of Clinton, Essex and Franklin Counties. He discovered, on that survey, the famous magnetic oxides of iron, since purchased by the State, in Clinton county, where the Clinton Penitentiary has been located, and made the first discovery of the peculiarities of the carbonized oxides of iron, in the town of Duane, known as "natural steel," and reported to the Legislature, in 1841, their value for the manufacture of cutlery and all kinds of edged tools.

He entered the law-office of Gen. Skinner at Plattsburg, New York, and there, and in the city of New York, devoted all his leisure hours to the study of law, with a view to that profession for life.

In 1842 he was induced to visit Russia, under assurances from the Russian Mirister at Washington, that his services would be accepted by the Emperor on the great railroads then in process 
of construction, unảer the supervision of Major G. W. Whistler, an eminent American engineer. But General Roberts could make no satisfactory terms with the Russian Government, as it required, at that day, the oath of allegiance from all foreigners, not embraced in the factory system, who should enter the civil or military lists. He declined the offer of a commission in the Eugineer Corps, and returned home in February of 1843. In the Spring of that year, he completed his law studies, and the following Summer, was admitted to the practice of law; and established himself at Fort Madison, Lee County, Iowa, and thus became one of the first and oldest settlers and citizens of Iowa.

In 1846, at the breaking out of the Mexican War, he applied to be commissioned in the Regiment of Mounted Riflemen, and was, by President Polk, appointed the ranking First Lieutenant. With that Regiment, that bore a more than notable share in the hardships, glories and successes of Gen. Scott's campaign and conquest of Mexico, he was not the least distinguished of its officers. He was at the seige of Vera Cruz and at its surrender. He commanded the advance guard of Twiggs' division ; and on the day it reached Vegara, completing the investment of the city, he surprised at that place and captured a large convoy of supplies for Vera Cruz, guarded by Lancers and Infantry.

On the 26th of March he fought the battle of Punte del Medio, and led the company that stormed the works.

He was promoted to the rank of Captain in February, 184.7.

He commanded a squadron of his regiment and led the regiment, in the memorable storming of the main heights of Cerro Gordo, April 18, 1847.

He was assigned to the command of selected stormers, and carried the lown of San Juan de los Llanos, by assault, on the 10th of August, 1847, capturing the stores and supplies of the Guerrillas, whose General was the Prefect of that place.

He commanded the advanced guard in the battle of Contreras, August 18, 1847.

He was at the head of his company in the battle of Cherrubusco on the 18th of August, 1847.

He commanded the picked storming party from Smith's brigade, at the capture of Chepultopec, on the 13th of September, 1847, and led this forlorn hope.

He was at the capture of the Gareta of Belin. 
He led the advance of Quitman's army into the City of Mexico, on the morning of the 14th of September, 1847, and was the first officer who entered the Capitol and raised, with his own hands, the first American Flag above the ancient palace of the Montezumas, that announced the capture of the proud city of their descendants, by the valor of American arms.

He was assigned to the command of one hundred picked men of his regiment, and four hundred volunteers, and fought the principal street fight in that city, on the 15 th, routing the forces of Santa Anna, led by him in person from Guadaloupe to the Gareta, in the belief that the Leperos in the city would rise, and, uniting with him, make a second Saragossa of the city of Mexico. This street fight and the slaughter of the enemy in the streets, by our picked riflemen, who worked their way over and through houses, put an end to further attempts of the Mexicans to recover the city or annoy our troops in its occupation.

He was transferred, in October, to the command of all the caralry in the District of Puebla, and on the 10th of November, 1847, surprised and defeated General Torrejon and Rhea, with seven hundred guerrillas at Tclascalla, capturing their main supplies of arms and subsistence, and recovering a large merchant train which these guerrilla chiefs had captured near St. Martine, en route for the City of Mexico.

Gen. Roberts was brevetted a Major and a Lieutenant Colonel, in the regular army, by President Polk, in consideration of his services in General Scott's campaign.

The Legislature of Iowa, in 1849, passed a joint resolution, presenting to General Roberts the thanks of the State, expressive of its appreciation of his services in the capture of the City of Mexico, and afterwards, by another resolution, bestowed upon him a sword of honor, presented by its Representatives in Congress at the Capitol in Washington.

At the breaking out of the present rebellion, General Roberts was on duty with his Regiment in New Mexico, and by his prudence, energy and foresight, the designs of the commanding officer of that Department and his traitorous accomplices, to turn that country over to the Southern Confederacy, with its troops, arms, Forts and supplies, were defeated. When Loring, Longstreet, and Sibley found their purposes discovered, they fled the country, and, in Texas, joined the traitors, and organized the expedition for the conquest of New Mexico, having failed to carry 
it out of the Union by treason and treachery, as Texas was carried out by the arch traitor Twiggs.

General Roberts was assigned by Gen. Canby to the command of the Southern District of New Mexico, fortified Fort Craig, and made the memorable defence of that place during the seige by Gen. Sibley, in January and February, 1862. He was in command at Valonde, and by the blows he there laid upon the Texans, opened the brilliant and successful field campaign against Gen. Sibley, that culminated at Peratta, with the utter route and retreat of their broken and defeated regiments back to Texas.

After the invasion of New Mexico had been rolled back, and the Federal posts and authority had been re-established in that Department, General Roberts was sent to Washington, bearing the trophies of the battles and the official reports of Gen. Canby, the commander of the country. He was appointed in July, 1862, by President Lincoln, a Brigadier General of Volunteers, in consideration of his services in defending and saving the Territory of New Mexico, and was ordered to report to Maj. Gen. John Pope.

In organizing the campaign of Virginia, Gen. Pope appointed General Roberts Chief of Cavalry, and afterwards Inspector General of his army. He was active and prominent in all the battles ar 7 combats of Gen. Pope's army, from Cedar Mountain to the Rappahannock, and along the line of that river, and in the desperate struggles of Friday and Saturday, the 29th and 30th of August, on the plains of Manassas, and on Monday at Chantilly; and is mentioned by Gen. Pope, in his official report, as entitled to distinguished honor and praise.

He was afterwards assigned to the command of Harper's Ferry, and subsequently to the command of an Independent Brigade in Western Virginia.

During the Spring campaign of 1863 , in Western Virginia, General Roberts displayed his usual military capacity and energy, by repelling a superior force of rebels, over ten thousand strong, under the rebel Generals Jones, Imboden, and W. L. Jackson. Having acquired certain information of their intention to cut off his small forces, scattered along a line of ninety miles, with his Head Quarters at Buchannon, General Roberts, by rapidly concentrating and marching his men, after despairing of reinforcements, and by destroying the bridge over Middle Fork, entirely frustrated the plans of attack by the enemy, mostly mounted and 
prorided with light artillery; and forced their march in the direction of Col. Mulligan, at Philippa, where they met with signal defeat. He was thus instrumental in saving Northwestern Virginia from being overrun by these rebel hordes, intent on the plunder of towns, and the destruction of railroads, in their route.

From Western Virginia, Greneral Roberts was assigned to the command of the Department of Iowa, on the 10 th of June 1863, at Davenport, which he has conduoted with prudence and ability, during a period of much excitement in prospect of a draft in this State. He was relieved from this Department, on the $2 \mathrm{~d}$ of Dec., 1863, and awaits his allotment, by the War Department, to active service in the field. Camp Roberts, at Davenport, is named in honor of him; and many personal friends will regret his departure.

Many more details of our Iowa General might be added, drawn, as are these mostly, from the Public Documents of Congress. For his earlier history, reference is especially made to the Congressional Documents of 1847 and 1848 .

The following extract from the official Report of Gen. Pope will show in what estimation his services were held, during that memorable campaign of the Army of the Potomac, in Eastern Virginia, in which Gen. Roberts bore so conspicuous a part:

"To Brigadier General Roberts, in particular, I am indebted for services, marked throughout by skill, courage, energy and judgment, and worthy of the solid reputation as a soldier, he has acquired by many previous years of faithful and distinguished military service."

Much more testimony from the public records of the country might be added, did space permit.

It will be seen, by the foregoing authentic sketch, that General Roberts is one whom th $\uplus$ State of Iowa has especially delighted to honor, for his distinguished military services. The sword, presented to him by the General Assembly of Iowa, is a splendid dragoon regulation sabre, in shape and size, with golden hilt and mountings, with the names and places of the battles above recited, as occurring in Mexico, engraven upon the blade of burnished steel, and costing six hundred dollars.

The Editor of the Annals subjoins here an extract from his correspondence, which relates to the Mexican armor and Guerrilla chief's sword, presented by General Roberts to the State, and by the State to the Historical Society at Iowa City.

The armor consists of a cuirass or helmet of brass, a breast- 
plate and back-plate of steel, covered with burnished brass, all weighing about thirty-five pounds. It was taken on the 13th of September, 1847, from eighty suits of the same kind, in the palace of the Montezumas, by Gen. Roberts, who was the first to enter it and raise the American flag there, as above stated.

The sword and its capture are more minutely described in the following letter :

Rev. SAM'L Stork Howe,

Davenport, Iowa, 14th Dec., 1863.

Librarian of the State Historical Society of Iowa:

Dear Sir:-I had the honor to receive, through Adjutant General Baker, your request to me, in these words: "Please say to General Roberts that I think I have found the silver-mounted sword that belongs with the Mexican armor, which he captured and gave to the State of Iowa, and the State gave to our Society. But I would much like an autograph letter account of its capture, since I find no history of it, in our brief archives, going back to 1857."

In complying with your request, I will state my recollections of the sword. It was a light, slightly curved, cavalry sabre, with basket handle guard, and leather scabbard, and mountings of alloyed silver, captured from General Torrejon, near Tclascalla, in old Mexico, on the 10th of November, 1847. That Chief of Guerrillas, with General Rhea, had captured and run off a large merchant train of supplies en route from Puebla to the City of Mexico, intended for sale to General Scott's army, that was in possession of the capital.

General Lane was, at that time, in command of the District of Puebla, and received intormation of this capture about nine o'clock P. M., of the 9th, and sent me orders to proceed, without delay, with all my cavalry force, in the direction of Telascalla, for the recovery of this train, and the dispersion of the Guerrillas, then known to be about seven hundred strong, in that beautiful and ancient city, where Cortez married the faithful and true Princess, Marianna.

I moved with six companies of cavalry, about four hundred and fifty strong, at 10 o'clock at night; and, at daylight in the morning, surprised and captured the city, with all the supplies of Torrejon, and thirteen of his principal officers. He escaped, having fleet and fresh horses, by virtue of speed and spur. But I pursued him, and a few other fugitives, so closely, that, after a 
chase of about two miles, he dismounted, and, taking a goat path up the chalk bluffs of the river, left his horse and most valuable papers in my possession. This sabre, after the style of Mexican cavalry, was fastened under the saddle-skirt, and thus it fell into my hands. I am certain that it is the sabre of that notable Guerrilla chief, as I was not fifty yards from him when he threw himself from his horse, and escaped over the chalk bluff's of the beautiful valley of the Tclascalla river, inaccessible to horses.

I am very truly yours,

B. S. ROBERTS, Brig. Gen. Vols.

The Editor adds, with many regrets, that he is unable to accompany this sketch with an engraved portrait of the person ts whom it relates. The General has an instinctive shrinking from any artistic display of himself, even for the gratification of his friends, preferring rather to face bullets and cannon balls. Indeed, his leisure is now occupied in perfecting newly invented musket balls, that will kill at one thousand yards, and shot and shell that will do like execution at two and a half or three miles, exploding upon contact with iron-clads and fortifications. 
Copyright of Annals of Iowa is the property of State of Iowa, by \& through the State Historical Society of Iowa and its content may not be copied or emailed to multiple sites or posted to a listserv without the copyright holder's express written permission. However, users may print, download, or email articles for individual use. 